\title{
An Autoactive Mutant of the M Flax Rust Resistance Protein Has a Preference for Binding ATP, Whereas Wild-Type M Protein Binds ADP
}

\author{
Simon J. Williams, ${ }^{1}$ Pradeep Sornaraj, ${ }^{1}$ Emma deCourcy-Ireland, ${ }^{1}$ R. Ian Menz,, ${ }^{1}$ Bostjan Kobe, ${ }^{2}$ \\ Jeffrey G. Ellis, ${ }^{3}$ Peter N. Dodds, ${ }^{3}$ and Peter A. Anderson ${ }^{1}$ \\ ${ }^{1}$ The School of Biological Sciences, Flinders University, Adelaide, Australia; ${ }^{2}$ School of Chemistry \& Molecular Bioscience, \\ Institute of Molecular Biosciences, and Centre for Infectious Disease, University of Queensland, Brisbane, Australia; \\ ${ }^{3} \mathrm{CSIRO}$, Division of Plant Industry, Canberra, Australia
}

Submitted 4 March 2011. Accepted 17 April 2011.

\begin{abstract}
Resistance $(\mathbf{R})$ proteins are key regulators of the plant innate immune system and are capable of pathogen detection and activation of the hypersensitive cell death immune response. To understand the molecular mechanism of $R$ protein activation, we undertook a phenotypic and biochemical study of the flax nucleotide binding (NB)-ARC leucine-rich repeat protein, M. Using Agrobacterium-mediated transient expression in flax cotyledons, site-directed mutations of key residues within the P-loop, kinase 2, and MHD motifs within the NB-ARC domain of $M$ were shown to affect $R$ protein function. When purified using a yeast expression system and assayed for ATP and ADP, these mutated proteins exhibited marked differences in the quantity and identity of the bound nucleotide. ADP was bound to recombinant wild-type $M$ protein, while the nonfunctional P-loop mutant did not have any nucleotides bound. In contrast, ATP was bound to an autoactive $M$ protein mutated in the highly conserved MHD motif. These data provide direct evidence supporting a model of $\mathbf{R}$ protein function in which the "off" $R$ protein binds ADP and activation of $R$ protein defense signaling involves the exchange of ADP for ATP.
\end{abstract}

Plant innate immunity can be divided into two strategies that differ, both in terms of the plant receptors that are involved in pathogen detection and in the pathogen-derived targets that are detected. As a first line of defense, plants recognize conserved macromolecules presented by the invader to activate a basal resistance response. This immune strategy is known as pathogen-associated molecular pattern (PAMP)-triggered immunity (PTI) and detection generally occurs within the extracellular space by PAMP recognition receptors (Chisholm et al. 2006; Jones and Dangl 2006). The second, more targeted, immune strategy is directed towards pathogens that have adapted to evade PTI. In such cases, plants recognize the pathogen by detecting specialized proteins that the pathogen secretes during the infection process (Bent and Mackey 2007; Panstruga and Dodds 2009). These proteins are termed effectors and are generally delivered into the plant cell, in which they function to

Corresponding author: Peter Anderson;

E-mail: peter.anderson@flinders.edu.au

* The $e$-Xtra logo stands for "electronic extra" and indicates that three supplementary figures and one supplementary table are published online. assist in pathogen colonization. Plants have evolved an array of different resistance $(\mathrm{R})$ proteins that recognize and respond to these specific pathogen effector proteins. Collectively, these $R$ proteins enable plants to resist infection by a broad range of pathogens, including viruses, bacteria, fungi, oomycetes, and nematodes. This defense strategy is defined as effector-triggered immunity (ETI) (Chisholm et al. 2006; Dodds and Rathjen 2010; Jones and Dangl 2006).

In order to initiate a targeted resistance response, $\mathrm{R}$ proteins possess pathogen surveillance and cell signaling functions. Detection of effector molecules has been demonstrated to occur by both direct and indirect interactions between $\mathrm{R}$ proteins and effectors (Dodds et al. 2006; Jones and Dangl 2006; Krasileva et al. 2010). Once activated, the $\mathrm{R}$ protein most likely undergoes a conformational change, transforming the protein from an inhibited to an active state, initiating transduction of a signal or signals to trigger defense responses. Unlike PTI, ETI results in a hypersensitive response (HR), which often culminates in programmed cell death at the infection site (Greenberg 1997).

The most prevalent class of $R$ genes encode tri-domain proteins with a central nucleotide-binding domain (NB), a C-terminal leucine-rich repeat (LRR) domain, and generally, either a coiled-coil (CC) or a toll-interleukin 1 receptor (TIR)-like domain at the N-terminus. Conserved motifs within the NB domain of $\mathrm{R}$ proteins are also conserved in the mammalian apoptotic protease-activating factor 1 (Apaf-1) and Caenorhabditis elegans cell death protein 4 (CED-4). Consequently, the NB domain of an R protein has been termed the NB-ARC, standing for a nucleotide-binding adaptor shared by APAF-1, certain $R$ gene products, and CED-4 (van der Biezen and Jones 1998). NB-ARC-LRR R proteins have also been included in a broader protein class known as signal transduction ATPases with numerous domains (STAND) (Leipe et al. 2004). STAND proteins are generally signaling hubs whose functions range from mediators of cell death and inflammation to regulators of transcription. For inclusion in the STAND classification, a protein must contain a NOD (nucleotide binding and oligomerization domain) module, which, in the case of $\mathrm{R}$ proteins, is the NB-ARC domain (Leipe et al. 2004).

Comparisons of a number of $\mathrm{R}$ proteins have identified conserved motifs within the NB-ARC domain (Meyers et al. 1999). These motifs cluster to three subdomains, designated NB, ARC1, and ARC2 (Albrecht and Takken 2006), that can be clearly defined in the crystal structures of Apaf-1 and CED-4 (Riedl et al. 2005; Yan et al. 2005). The NB domain 
contains the hallmark motifs, including the P-loop and kinase 2 , commonly found in nucleotide binding and hydrolysis proteins (Traut 1994). The P-loop motif contains an invariant lysine residue critical for nucleotide binding (Traut 1994). In the crystal structure of Apaf1, this lysine interacts directly with the bound $\beta$-phosphate of ADP (Riedl et al. 2005). Not surprisingly, mutation of this lysine in a number of $\mathrm{R}$ proteins has been shown to abolish activation of the resistance response (Bendahmane et al. 2002; Dinesh-Kumar et al. 2000; Howles et al. 2005; Tameling et al. 2002; Tao et al. 2000). Other mutations within the NB-ARC domain also result in loss or gain-of-function phenotypes (Tameling et al. 2006), demonstrating that the integrity of these motifs and the NB-ARC domain is critical in maintaining $\mathrm{R}$ protein function. The methionine-histidine-aspartate (MHD) motif at the C-terminal end of the ARC2 domain seems to play a critical role in regulating the switch between the inactive and active signaling states. Mutations to the conserved histidine and aspartate residues of this motif result in gain-of-function, or autoactive, phenotypes in a number of NB-ARC-LRR R proteins; that is, these mutants constitutively signal defense responses independently of effector recognition (Bendahmane et al. 2002; de la Fuente van Bentem et al. 2005; Howles et al. 2005; Tameling et al. 2006; van Ooijen et al. 2008a). The effect of such mutations on the nucleotide binding capability of an $\mathrm{R}$ protein is, however, unknown.

The first biochemical investigation of the NB-ARC domain involved the tomato $R$ genes $I-2$ and $M i l$. A recombinant protein consisting of the CC-NB-ARC region of I-2 (designated I$2 \mathrm{~N}$ ) was expressed in Escherichia coli and resolubilized from inclusion bodies. In this form, the protein was demonstrated to possess ATP binding and hydrolysis capabilities (Tameling et al. 2002). Importantly, when the invariant lysine within the $P$ loop of I-2N was mutated to arginine, both the nucleotide binding and hydrolysis capabilities of the recombinant protein were significantly reduced. The same mutant was inactive in planta, indicating a role for either ATP binding, hydrolysis, or both in $\mathrm{R}$ protein function. In a subsequent study, it was shown that I-2N formed a stable interaction with ADP; however, it could not be captured in an ATP-bound state (Tameling et al. 2002). Mutations in which the aspartate in the kinase 2 motif was changed to glutamate and a serine in the RNBS-A motif (Meyers et al. 1999) was changed to phenylalanine were both autoactive in planta. Purified recombinant forms of these two mutant proteins showed a reduced rate of ATP hydrolysis activity compared with the nonmutated I- $2 \mathrm{~N}$ protein but had similar Km values, suggesting that the ATP binding affinities were similar (Tameling et al. 2006). These data indicate that the autoactive phenotype was caused by the protein spending a longer period of time bound to ATP due to its reduced rate of hydrolysis. This led to a model in which the identity of the bound nucleotide within the NB pocket of the R protein is the crucial feature controlling activation. In this model, termed "molecular switch," an R protein in an inactive or "off" state is ADP bound and in an active or "on" state is ATP bound. Furthermore, hydrolysis of the bound ATP could enable the protein to reset to the ADP-bound inactive state (Takken et al.
2006; Tameling et al. 2006). A similar model has also been proposed for other members of the STAND protein class, including the NB-LRR receptors (NLR) involved in innate immunity in animal (Faustin et al. 2007). One report that is inconsistent with this model is that from Ueda and associates (2006). Here, an NB-ARC-LRR fragment of the tobacco Tobacco mosaic virus (TMV) resistance protein $\mathrm{N}$ was purified from $E$. coli, and it was suggested that ATP binding to N proceeded the interaction with the TMV helicase p50 effector (Ueda et al. 2006). Both of these $R$ protein studies are limited by the fact that they were performed using domain truncations of $\mathrm{R}$ proteins. Although the molecular switch model is generally favored to explain $\mathrm{R}$ protein activation, numerous aspects of the model have not been demonstrated, including a lack of direct experimental evidence demonstrating that an activated $\mathrm{R}$ protein binds ATP.

In an effort to further understand $\mathrm{R}$ protein activation, we investigated the ADP/ATP binding capabilities of two resistance proteins, $\mathrm{M}$ and L6, which confer rust (Melampsora lini) resistance in flax (Linum usitatissimum) (Anderson et al. 1997; Lawrence et al. 1995). We demonstrated that recombinant, tri-domain, $\mathrm{M}$ and L6 proteins were purified bound to endogenously-derived ADP. A mutation in the conserved Ploop motif that inactivates the $\mathrm{M}$ protein's ability to trigger the resistance response was not bound to a nucleotide in the corresponding recombinant protein. This result suggests that mutation of the conserved lysine abolishes nucleotide binding in $\mathrm{M}$, an idea consistent with published data from other $\mathrm{R}$ and STAND proteins. Our analysis of two putative gain-offunction mutations demonstrated that, while a mutation in the MHD motif caused autoactivity in M, a mutation in the kinase 2 motif, responsible for gain-of-function phenotypes in I-2 and Rps5 (Ade et al. 2007; Tameling et al. 2006), did not. Importantly, the autoactive MHD mutant of $\mathrm{M}$ had significantly more ATP bound than ADP. This data supports an important aspect of the model of $\mathrm{R}$ protein activation, whereby the ADP-bound protein form is the "off" state, while the active state of the protein is ATP-bound.

\section{RESULTS}

\section{Mutations within the NB-ARC domain of $M$ affect in planta function.}

Many mutations within the NB-ARC domain of $\mathrm{R}$ proteins have been demonstrated to cause loss- and gain-of-function phenotypes in planta. To define the phenotypic consequences of three $M$ gene mutations (Table 1; Supplementary Fig. 1), we first established an in planta assay for $M$ protein function based on Agrobacterium-mediated transient expression in flax cotyledons. Plant expression constructs contained genomic versions of the $M$ and mutant $M$ genes downstream of the Cauliflower mosaic virus $35 \mathrm{~S}$ promoter, with a C-terminal influenza hemagglutinin (HA) epitope tag. The coding sequences of avirulent $(A v r M)$ and virulent ( $a v r M)$ were also downstream of the $35 \mathrm{~S}$ promoter in the pTNSpec expression vector (Catanzariti et al. 2006). Cotyledons were monitored up until 9 days postinfiltration (dpi), and $\mathrm{M}$ protein expression levels

Table 1. Mutations generated in $\mathrm{M}$ and the in planta affects observed from Agrobacterium transient expression experiments

\begin{tabular}{lll}
\hline Substitution in M & Motif & Putative affect (reference) \\
\hline K286L & P-loop & Loss-of-function (Bendahmane et al. 2002; Dinesh-Kumar et al. 2000; Howles et al. \\
& 2005; Tameling et al. 2002; Tao et al. 2000) & Observed affect \\
K364E & Ginase-2 & Gain-of-function (Ade et al. 2007; Tameling et al. 2006) \\
D555V & Gain-of-function (Bendahmane et al. 2002; de la Fuente van Bentem et al. 2005; & Same as wildtype \\
K286L+D555V & P-loop/MHD & Loss-of-function (Tameling et al. 2006)
\end{tabular}


were monitored by anti-HA immunoblot analysis of samples from 1, 2, 3, 4, and 9 dpi (Fig. 1).

Consistent with the gene-for-gene basis of the interaction, a necrotic response indicative of activation of the HR was first observed 3 dpi in coinfiltrations of $M$ and $A v r M$ (Fig. 1A) but not when $M$ and $a v r M$ were coinfiltrated (Fig. 1B). No phenotype was observed when the $M$ gene was expressed on its own (Fig. 1C). A mutant version of $\mathrm{M}$ containing a lysine to leucine substitution in the P-loop motif $\left(M^{K 286 L}\right)$ abolished the AvrMdependent necrosis (Fig. 1A). This confirmed that, like many other $\mathrm{R}$ proteins, mutation of the highly conserved lysine in the P-loop motif renders the $\mathrm{M}$ protein nonfunctional.

Two putative autoactive mutants, $M^{D 555 V}$ and $M^{D 364 E}$, were designed with reference to mutations in other $\mathrm{R}$ proteins that conferred an autoactive phenotype (Bendahmane et al. 2002; de la Fuente van Bentem et al. 2005; Howles et al. 2005; Tameling et al. 2006; van Ooijen et al. 2008a). The D364E mutation alters the second invariant aspartate residue in the kinase 2 domain, which was autoactive in both I-2 and Rps5. This mutation did not lead to an autoactive phenotype in $\mathrm{M}$, yet when coexpressed with AvrM, the HR was induced, although slightly delayed compared with wild type (Fig. 1A). In contrast, a HR independent of AvrM was induced at 4 dpi by the expression of $\mathrm{M}^{\mathrm{D} 555 \mathrm{~V}}$ (Fig. 1C). Incorporation of the lysine to leucine change in the P-loop motif of $\mathrm{M}^{\mathrm{D} 55 \mathrm{~V}}$, designated $\mathrm{M}^{\mathrm{K} 286 \mathrm{~L}+\mathrm{D} 555 \mathrm{~V}}$, inactivated the autoactive response (Fig. 1C), indicating that a functional P-loop is required for $M^{D 555 V}$-mediated autoactivity.

To assess M protein expression levels in Agrobacterium-infiltrated flax cotyledons, total protein was extracted and was subjected to an anti-HA immunoblot. All $\mathrm{M}$ and mutant $\mathrm{M}$ proteins were detected between 2 and 9 dpi in single infiltrations, with the exception of $M^{D 555 V}$. Here $M^{D 555 V}$ was undetectable after 3 dpi (Fig. 1C) and was not detectable when coexpressed with either AvrM or avrM (Fig. 1A and B). Similar but reduced levels of expression were observed in coinfiltrations of $M$ and mutant $M$ genes with $a v r M$ (Fig. 1B). In contrast, only the $\mathrm{M}^{\mathrm{K} 286 \mathrm{~L}}$ protein was detected in coinfiltrations with AvrM, however, only at 9 dpi (Fig. 1A). The Rubisco large subunit protein was used to assess protein loading in sodium dodecyl sulfatepolyacrylamide gel electrophoresis (SDS-PAGE) gels. We also found that the loss of Rubisco correlated with total protein loss, making Rubisco levels indicative of total protein degradation in infiltrated cotyledons undergoing HR. Similar Coomassie blue staining of Rubisco was observed in all samples, except when the $\mathrm{M}$ and $\mathrm{M}^{\mathrm{D} 364 \mathrm{E}}$ proteins were activated by $A v r M$ or the protein was autoactive $\left(M^{D 555 V}\right)$. These data suggest that activation of the HR by effector recognition leads to preferential loss of the M protein.

\section{Recombinant $M$ and L6 contain tightly bound ADP.}

We previously reported a protocol for the production and purification of the soluble tri-domain flax $\mathrm{R}$ proteins, $\mathbf{M}^{21-1305}$ and L6 $6^{29-1294}$ (designated M and L6, respectively), using the Pichia pastoris expression system (Schmidt et al. 2007) (Fig. 2A). In an effort to make this procedure more amenable to protein production for biochemical analysis, a number of changes were made to the published procedure. A one-step nickel affinity (NiA) purification procedure was adopted, and the starting material was scaled down from fermentor-grown cultures yielding $500 \mathrm{~g}$ of wet cell weight (wcw) pellets to 3-g wcw pellets grown in shaker flasks. With these adjustments, both $\mathrm{M}$ and L6 proteins could be purified directly from $P$. pastoriscleared cell lysates (Fig. 2B and C). Typical protein yields of 20 to $40 \mu \mathrm{g}$ per gram of wcw pellet were obtained at 50 to $70 \%$ purity (from visual inspection of Coomassie blue-stained SDS-PAGE gels). After elution from the NiA column, the pro- tein was concentrated to $1 \mathrm{ml}$. M and L6 proteins were denatured by boiling and were removed by centrifugation, and the released nucleotides were measured using a luciferase assay (based on that described by Marquenet and Richet [2007]). We also used this procedure to measure the nucleotide levels in protein still present after $\mathrm{NiA}$ chromatography from induced $P$. pastoris cells transformed with the pPICZ vector alone (Fig. $2 \mathrm{C}$, empty vector control). ADP concentrations of $3.3 \times 10^{-7}$ and $2.5 \times 10^{-7} \mathrm{M}$ were observed in samples containing $\mathrm{M}$ and L6 protein, respectively, while the empty vector control contained $4.9 \times 10^{-8} \mathrm{M}$ (at least fivefold less than M or L6) (Fig. 2D). From these experiments, it was concluded that preparations of purified $\mathrm{M}$ and L6 protein were associated with endogenous ADP (Fig. 2D). Negligible amounts of ATP were detected in all samples.

To determine if the ADP was associated directly with recombinant $\mathrm{M}$ protein, NiA-purified $\mathrm{M}$ was subjected to gel filtration (GF), and the resulting fractions were analyzed for the presence of ADP. Immunoblot analyses of fractions from GF revealed that the $M$ protein elutes in a size range consistent with that expected for a monomeric form of the protein (molecular mass $=147 \mathrm{kDa}$ ) (Fig. 3A). ADP quantification of these fractions revealed a strong correlation between the elution profile of $\mathrm{M}$ and ADP, supporting the conclusion that ADP is associated with a monomeric form of the wild-type $M$ protein (Fig. 3B). Furthermore, the ADP had remained associated with $M$ throughout the purification procedure (approximately $6 \mathrm{~h}$ ), indicating that although ADP dissociates from the protein, it is tightly bound.

\section{Quantitative analysis of endogenous nucleotide associated with $M$ and $M$ mutant proteins.}

Given that ADP was found bound to M and L6, we turned our attention to the nucleotides bound to the NB-ARC mutants of $\mathrm{M}$ described above. In order to do this, we first needed to determine the mole-to-mole ratio of purified protein to bound nucleotide. This required a method to accurately determine $\mathrm{M}$ protein concentration. As the protein preparations still contained P. pastoris host proteins (Fig. 2B), an estimate of total protein measured using a standard assay was not appropriate. To specifically measure the concentration of $\mathrm{M}$ protein in purified protein extracts, Sypro Ruby staining of the 147-kDa M protein band was quantified against a standard curve generated from known amounts of bovine serum albumin (BSA) run on the same SDS-PAGE gel (Supplementary Fig. 2). Using this strategy, the mole-to-mole ratio of either ADP, ATP, or both to protein could be estimated, and we subsequently recorded this as percent (\%) occupancy. To accurately calculate the percent occupancy, the amounts of ADP and ATP obtained for $P$. pastoris cells containing the pPICZ empty vector control samples were subtracted from the values obtained for all protein samples.

Using these methods, the nucleotide occupancy of $\mathrm{M}$ was calculated to be $35 \pm 3 \%$ ADP bound and $2 \pm 0.1 \%$ ATP bound (Fig. 4). The following mutant proteins were then purified from P. pastoris: $\mathrm{M}^{\mathrm{K} 286 \mathrm{~L}}, \mathrm{M}^{\mathrm{D} 364 \mathrm{E}}, \mathrm{M}^{\mathrm{D} 555 \mathrm{~V}}$, and $\mathrm{M}^{\mathrm{K} 286 \mathrm{~L}+\mathrm{D} 555 \mathrm{~V}}$. All proteins were expressed to similar levels as the wild-type protein and were soluble. Mutation of the P-loop lysine $\mathrm{M}^{\mathrm{K} 286 \mathrm{~L}}$ completely abolished nucleotide binding, thus confirming that the bound nucleotide detected in the purified wild-type $\mathrm{M}$ protein is bound to the NB-ARC domain. Compared with the wild-type $\mathrm{M}$ protein, purified $\mathrm{M}^{\mathrm{D} 364 \mathrm{E}}$ protein had significantly higher levels of bound ADP, equivalent to $104 \pm 4.7 \%$. In contrast, the autoactive $\mathrm{M}^{\mathrm{D} 555 \mathrm{~V}}$ protein was purified with significant amounts of ATP (18 $\pm 4 \%$ occupancy) and less ADP (5.40 \pm $2 \%)$ than wild-type protein. The $\mathrm{M}^{\mathrm{K} 286 \mathrm{~L}+\mathrm{D} 555 \mathrm{~V}}$ protein contained negligible levels of ATP and ADP (Fig. 4). 


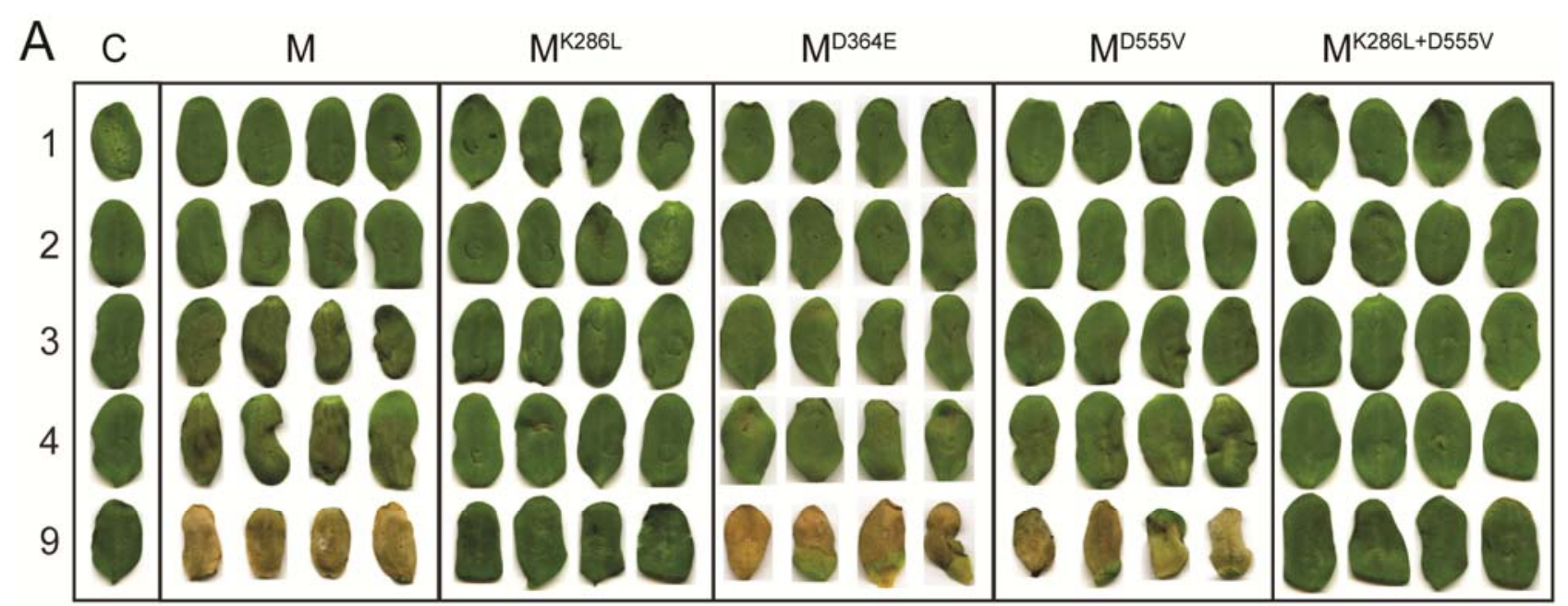

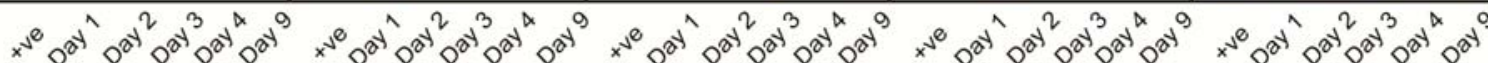

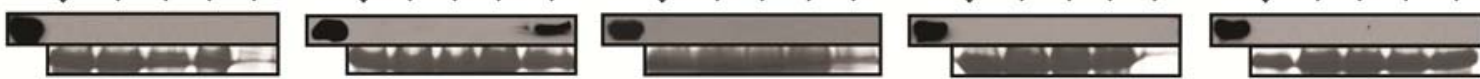
B C M $\mathrm{M}^{\mathrm{K} 286 \mathrm{~L}}$
$\mathrm{M}^{\mathrm{D} 364 \mathrm{E}}$
$\mathrm{M}^{\mathrm{D} 555 \mathrm{~V}}$
$M^{K 286 L+D 555 V}$

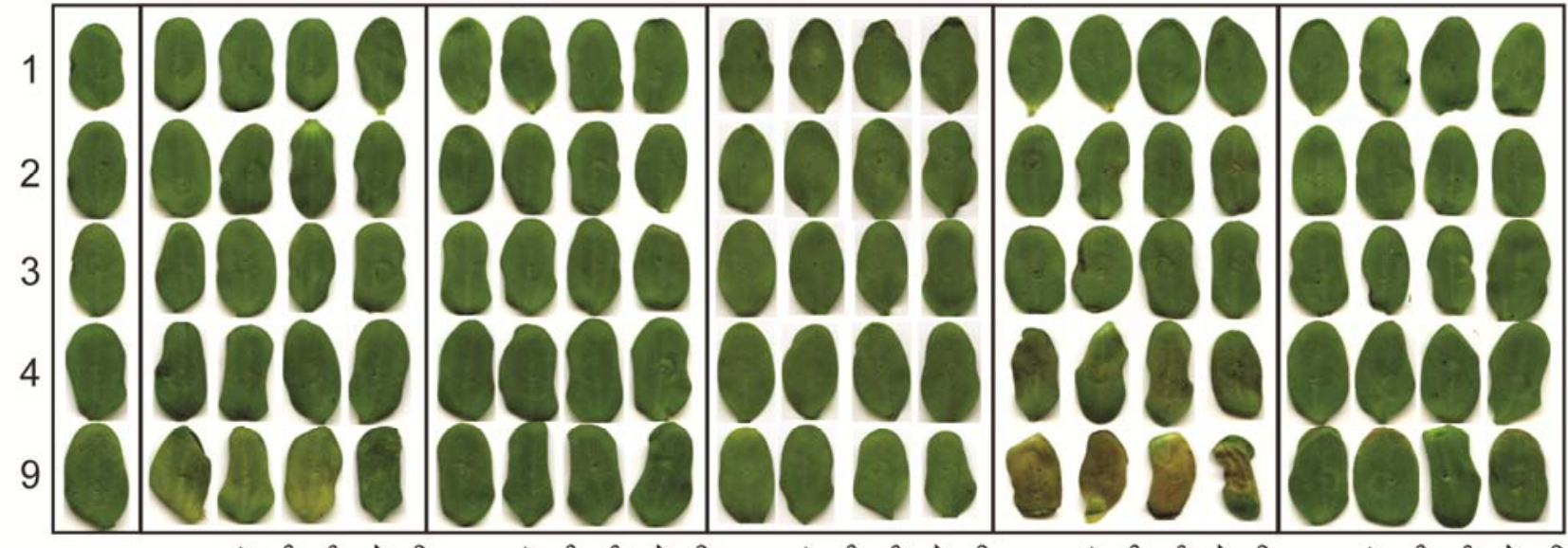

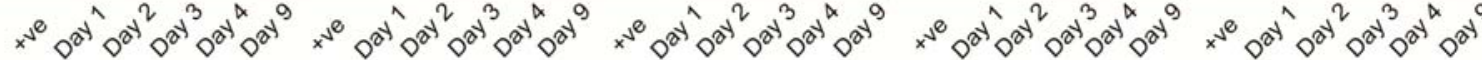

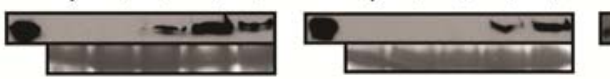
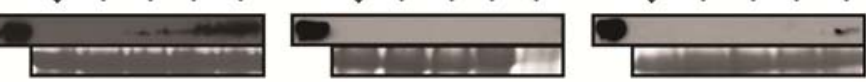

C

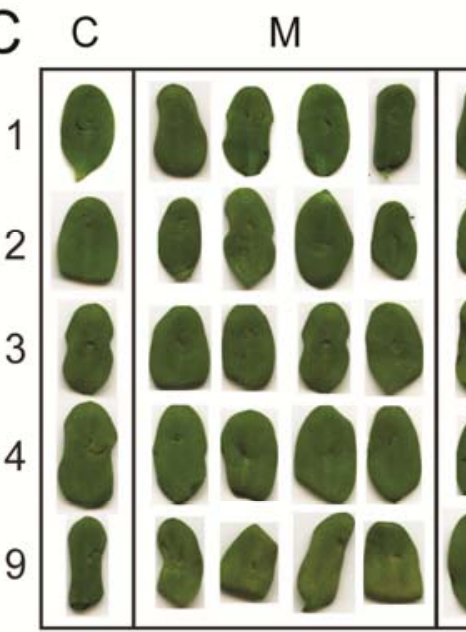
$\mathrm{M}^{\mathrm{K} 286 \mathrm{~L}}$

$\mathrm{M}^{\mathrm{D} 364 \mathrm{E}}$

$M^{\mathrm{D} 555 \mathrm{~V}}$

$M^{K 286 L+D 555 V}$

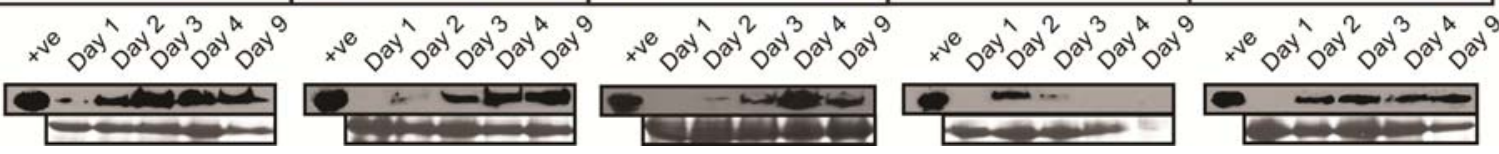




\section{DISCUSSION}

Although $\mathrm{R}$ proteins play a crucial role in plant innate immunity, the molecular mechanisms involved in their regulation and activation remain unclear. Using a combined phenotypic and biochemical analysis of mutants within the NB-ARC domain of the flax M protein, we provide an insight into the molecular requirements for $\mathrm{R}$ protein activation. We show that $\mathrm{M}$ and the related protein L6 are purified from $P$. pastoris bound to ADP. Furthermore, we demonstrate that a mutation within the P-loop of the NB pocket of $\mathrm{M}$, shown in other R proteins to abolish $\mathrm{R}$ protein function (Tameling et al. 2002; Ueda et al. 2006), prevents nucleotide binding. Significantly, a mutation in the MHD motif that results in autoactivity $\left(\mathrm{M}^{\mathrm{D} 555 \mathrm{~V}}\right)$ is copurified with both ATP and ADP. Our analysis of this autoactive mutant provides direct evidence that ATP binding is involved in an activated form of the protein and, thereby, supports a model that to transition from an inactive to an active state, $M$ is likely to exchange its bound nucleotide from ADP to ATP.

\section{Mutations in the NB-ARC domain affect protein function.}

Numerous loss- and gain-of-function mutations of $\mathrm{R}$ proteins are localized to motifs within the NB-ARC domain, thus indicating that the integrity of these motifs is required for correct $\mathrm{R}$ protein function (Takken et al. 2006). We targeted functionally important residues within the P-loop, kinase 2, and MHD motifs of M. As expected, mutation of the P-loop lysine to a leucine $\left(\mathrm{M}^{\mathrm{K} 286 \mathrm{~L}}\right)$ resulted in loss of $\mathrm{R}$ protein function, while an autoactive phenotype was observed when the aspartate in the MHD motif was mutated to valine ( $\left.\mathrm{M}^{\mathrm{D} 555 \mathrm{~V}}\right)$.

Changing the second aspartate of the kinase 2 motif to a glutamate $\left(\mathrm{M}^{\mathrm{D} 364 \mathrm{E}}\right)$, shown previously to cause autoactivity in I-2 and Rps5 (Ade et al. 2007; Tameling et al. 2006), did not affect $\mathrm{M}$ protein function. In the recombinant $\mathrm{I}-2 \mathrm{~N}$ protein, the analogous mutant $\mathrm{I}-2 \mathrm{~N}^{\mathrm{D} 283 \mathrm{E}}$ has a reduced ATP hydrolysis activity (Tameling et al. 2006). As this residue is predicted to provide the catalytic base required for ATP hydrolysis (Hanson and Whiteheart 2005), Tameling and coworkers (2006) speculated that $\mathrm{I}-2^{\mathrm{D} 283 \mathrm{E}}$ protein is autoactive in planta, when ATP is locked in the NB pocket. In our biochemical study, we observed higher ADP occupancies in the $\mathrm{M}^{\mathrm{D} 364 \mathrm{E}}$ protein compared with wild type, a possible result of increased ADP binding affinity. The result was not surprising, given our in planta observations; however, these results do differ from the observations made in I-2 and Rps5. One interesting feature of the kinase 2 motif is that the consensus sequence differs between the non-TIR $R$ proteins, of which I-2 and Rps5 are members, and the TIR containing $R$ proteins, which includes $M$ (Meyers et al. 1999). The consensus sequence in the non-TIR class identifies that the highly conserved double aspartate residues precede a valine followed by a tryptophan (DDVW), while in the TIR class, these positions are generally occupied by a valine followed by an aspartate (DDVD). It is, therefore, plausible that the positioning of this additional aspartate may provide the TIR class with a level of functional redundancy within the kinase 2 motif. However, without a crystal structure of the NB pocket of M, I-2, or Rps5, it is difficult to speculate exactly why different phenotypes result from these similar mutations.

During the transient expression of $M^{D 555 V}$, the protein could be detected at 2 and 3 dpi but was undetectable thereafter. When active and autoactive forms of $\mathrm{M}$ were coinfiltrated with AvrM, HA-tagged protein was not detected at any timepoint. Despite the absence of detectable protein, AvrM-activated M and $\mathrm{M}^{\mathrm{D} 364 \mathrm{E}}$ proteins were capable of inducing the HR in AvrM coinfiltrated cotyledons. This indicates that the threshold of AvrM-activated M protein is below the detection threshold of our immunoblot assay. When $\mathrm{M}$ and avrM were coexpressed in flax cotyledons, $M$ protein was detectable, albeit a day later than when expressed on its own. This can be explained by the dilution of $M$-containing Agrobacterium cultures with an equal volume of inoculum containing avrM. When Agrobacterium culture containing $M$ was coinfiltrated with GV3101, we observed a delay in $M$ protein detection from day 2 to day 3 (Supplementary Fig. 3). This delay is observed in all single infiltration (Fig. 1C) experiments compared with coinfiltration (Fig. 1B) experiments, with the exception of the double mutant $\mathrm{M}^{\mathrm{K} 286 \mathrm{~L}+\mathrm{D} 555 \mathrm{~V}}$ protein. In this case, $\mathrm{M}^{\mathrm{K} 286 \mathrm{~L}+\mathrm{D} 555 \mathrm{~V}}$ was not detected when expressed in the presence of AvrM and may reflect a reduced stability of this protein in the presence of the effector.

In $\mathrm{M}^{\mathrm{D} 555 \mathrm{~V}}$ and $\mathrm{M} / \mathrm{AvrM}$ coinfiltrated cotyledons, we observed the degradation of total cellular proteins in tissue undergoing the HR after 9 dpi, as evident by the breakdown of the large subunit of Rubisco. We observe that the loss of $\mathrm{M}$ protein precedes this global protein degradation. One explanation for this preferential loss of $\mathrm{M}$ is that, once activated, $\mathrm{M}$ protein is rapidly turned over in the cell. This is somewhat consistent with the findings of Boyes and associates (1998), who reported the degradation of the Arabidopsis resistance protein RPM1 (Boyes et al. 1998). Although preferential M protein degradation following activation may be occurring, we cannot rule out the possibility that the decrease in M protein levels associated with activation is a result of negative regulation of $M$ gene expression at the transcriptional level.

\section{ADP bound is the off state.}

The tri-domain $\mathrm{M}$ and L6 proteins were purified from $P$. pastoris with ADP bound, consistent with that found for other STAND proteins. For example, MalT was purified as a monomer bound to endogenous ADP (Marquenet and Richet 2007), while biochemical and structural studies of Apaf-1 have shown that an autoinhibited form of the Apaf-1 protein is either dADP or ADP bound (Bao et al. 2007; Riedl et al. 2005). Other biochemical evidence suggest that Apaf-1 is dATP bound and that the hydrolysis of dATP to dADP precedes its activation (Kim et al. 2005)

In the case of $\mathrm{R}$ proteins, a truncated version of the tomato I-2 protein lacking the LRR (I-2N) was capable of forming a stable complex with ADP, while an I-2N ATP complex could not be captured experimentally (Tameling et al. 2006). Accord-

Fig. 1. Functional analysis of $\mathrm{M}$ and nucleotide binding (NB)-ARC mutants. A, The $\mathrm{M}^{\mathrm{K} 286 \mathrm{~L}}$ protein is inactive in flax cotyledons. Flax cotyledons were coinfiltrated with Agrobacterium cultures containing M, M ${ }^{\mathrm{K} 286 \mathrm{~L}}, \mathrm{M}^{\mathrm{D} 364 \mathrm{E}}, \mathrm{M}^{\mathrm{D} 555 \mathrm{~V}}$, or $\mathrm{M}^{\mathrm{K} 286 \mathrm{~L}+\mathrm{D} 555 \mathrm{~V}}$ constructs and Agrobacterium cultures containing the AvrM construct. Images of the cotyledons were taken at 1, 2, 3, 4, and 9 days postinfiltration (dpi). Untransformed Agrobacterium sp. strain GV3101 was infiltrated as a control (lane C). Total flax cotyledon proteins were extracted at each timepoint and were subjected to sodium dodecyl sulfate-polyacrylamide gel electrophoresis (SDS-PAGE) and were immunoblotted using an anti-HA (hemagglutinin) antibody. Total flax cotyledon protein from each timepoint was also separated by SDS-PAGE, and the large subunit of Rubisco at $50 \mathrm{kDa}$ is shown stained with Coomassie blue as a control for equal protein loading and total protein degradation. Lane +ve contains recombinant M protein engineered with a C-terminal HA tag expressed and purified from the Pichia pastoris cells. B, M activation requires the cognate AvrM gene. Coinfiltrations were as described in A, except the Agrobacterium cultures containing the avrM construct were used instead of AvrM. C, The $\mathrm{M}^{\mathrm{D} 555 \mathrm{~V}}$ protein is autoactive in flax cotyledons. Infiltrations were as described for A, except neither AvrM or avrM-containing Agrobacterium cultures were used as a coinfiltrating innoculum. 
A
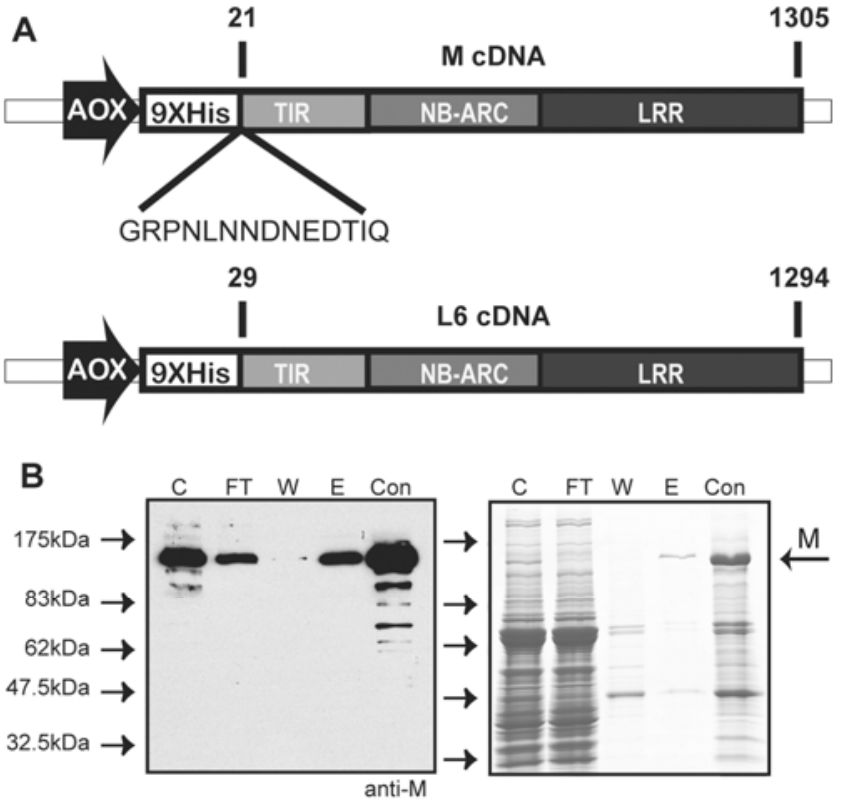

C

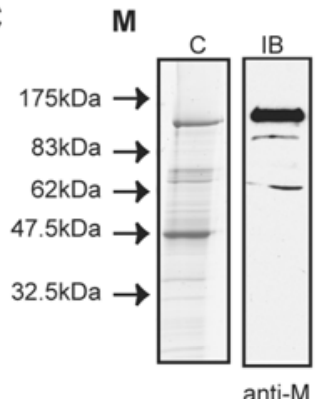

L6
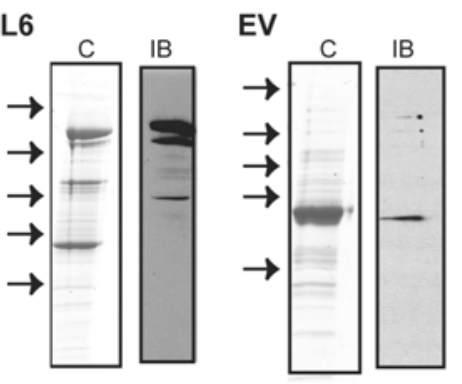

anti-His

anti-His

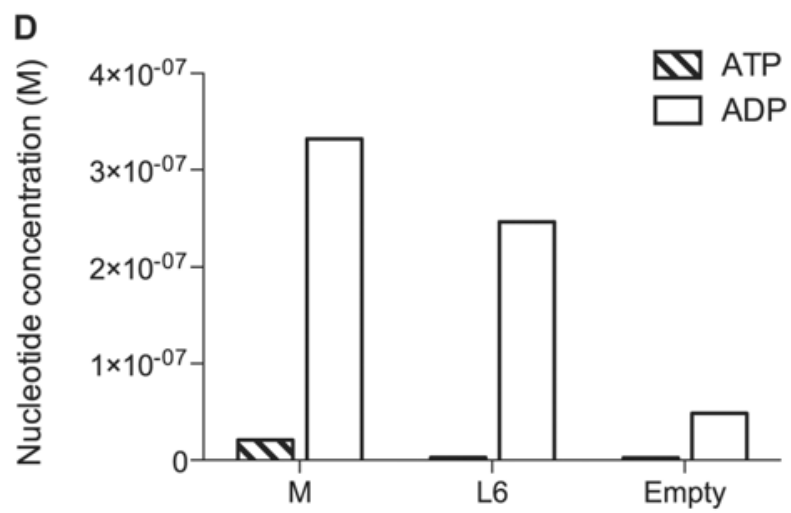

Fig. 2. ADP copurifies with recombinant flax R proteins $M$ and L6. A, A schematic diagram of the cloning vector (pPICz) containing the M cDNA (above) and L6 cDNA (below). Expression in Pichia pastoris is under the control of the alcohol oxidase (AOX) promoter, and the domains of the protein are designated TIR (toll interleukin 1), NB-ARC (nucleotide binding), and LRR (leucine-rich repeat). For M and L6, N-terminal truncations were made at residues 21 and 29, respectively. The N-terminal anti-M epitope is highlighted (Schmidt et al. 2007). B, Immunoblot analysis using an anti-M antibody (Schmidt et al. 2007) (left) and Coomassie stain analysis (right) showing the presence and absence of the $\mathrm{M}$ protein during purification. $\mathrm{C}=$ crude lysate, $\mathrm{FT}=$ nickel affinity chromatography flow through, $\mathrm{W}=55 \mathrm{mM}$ imidazole wash, $\mathrm{E}=250 \mathrm{mM}$ imidazole elution, $\mathrm{Con}=\mathrm{con}-$ centrated protein after nickel affinity chromatography. $\mathbf{C}$, Coomassie blue stain (C) and immunoblot (IB) analysis of the concentrated nickel elution fractions from M, L6, and empty vector purifications. Immunoblot analysis of $\mathrm{M}$ was performed with the anti-M antibody, whereas the L6 and the empty vector blot were probed with anti-His antibody. D, Samples shown in $\mathrm{C}$ were analyzed for the presence of adenosine nucleotides using a luciferase nucleotide quantification assay. ing to our interpretation of these data, approximately $4 \%$ of the $\mathrm{I}-2 \mathrm{~N}$ protein used in these filter-binding assays was bound to ADP and the remainder was likely to be incorrectly refolded. We observed higher ADP occupancies, approximately $35 \%$, in wildtype $\mathrm{M}$ protein, and while we cannot rule out some level of protein instability as a cause for occupancy values lower than $100 \%$, we suspect that nucleotides disassociate from the wildtype $\mathrm{M}$ protein during the purification process. This is supported by our GF data, whereby the appearance of ADP in nonprotein fractions (fractions 100 to $105 \mathrm{ml}$ ) indicates that ADP is disassociating from the $M$ protein during the mobile phase of GF. Recently, similar observations have been made for the CC-NBARC-LRR protein MLA21 (Maekawa et al. 2011). Monomeric MLA21 protein, expressed and purified from insect cells, is

A

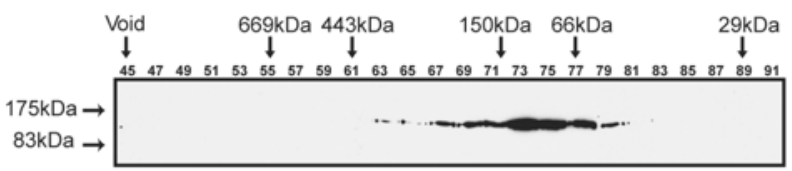

B

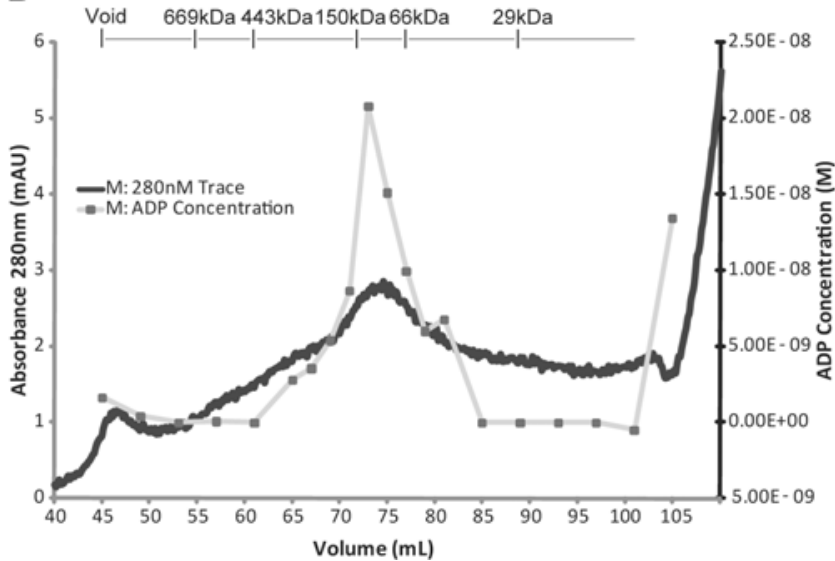

Fig. 3. ADP associated with monomeric $M$ protein. A, After nickel affinity (NiA) chromatography, concentrated M protein was further separated over a Superdex 200 PG gel filtration (GF) column, and the resulting fractions were analyzed by immunoblot, using the anti-M antibody. B, An ADP quantification assay was performed on fractions between 45 and $105 \mathrm{mls}$ of elution volume from GF, and the ADP concentration of each fraction was plotted on a graph that includes the optical density at $280 \mathrm{~nm}$ protein trace.

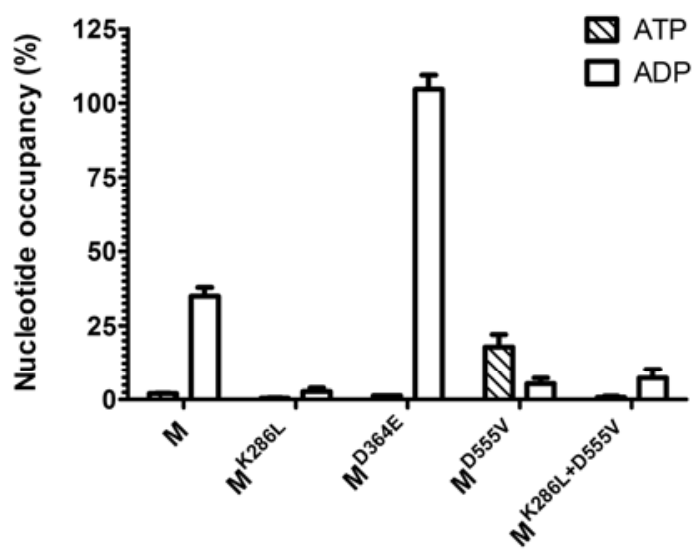

Fig. 4. ATP and ADP quantification of M and M-mutants. The percent of $\mathrm{M}$ and $\mathrm{M}$-mutant proteins occupied with ATP and ADP was determined after nickel affinity purification and concentration. Error bars represent the standard error from four independent purifications. Empty vector values were subtracted prior to occupancy calculations. 
demonstrated to be ADP-bound and this nucleotide disassociates from the protein during its migration through a GF column (Maekawa et al. 2011). These data are consistent with that of the $\mathrm{M}$ protein reported here and collectively support the idea that $\mathrm{R}$ proteins are held in an ADP-bound state.

As part of this study attempts were made to demonstrate nucleotide rebinding and ATP hydrolysis by $\mathrm{M}$ and mutant $\mathrm{M}$ proteins. These assays were also done in the presence and absence of purified AvrM protein. Issues of low M-protein yield and purity made these experiments technically challenging, and at this stage, we cannot report on the capacity of purified $\mathrm{M}$ protein to rebind ATP, hydrolyze it, or whether the presence of purified AvrM has any impact on these biochemical properties.

While the data presented in this study is consistent with that of I- $2 \mathrm{~N}$, we cannot rule out the possibility that the removal of the LRR domain changes the accessibility of the nucleotidebinding pocket and, thus, the dynamics of the I- $2 \mathrm{~N}$ proteinnucleotide interaction. The involvement of the LRR in regulating R-protein activity has been suggested from both domain coexpression studies of the NB-ARC-LRR protein Rx (Moffett et al. 2002) and in planta analysis of LRR-truncated variants of RPS2, RPS5, and RPP1A, which were autoactive (Ade et al. 2007; Tao et al. 2000; Weaver et al. 2006). In an effort to compare our results more directly with those published for I- $2 \mathrm{~N}$, we tried to express and purify a LRR truncation of M; however, this protein was highly unstable and was purified with very low yields.

\section{ATP binding and $R$ protein activation.}

The suggestion of an ATP-bound active $\mathrm{R}$ protein emerged when two autoactive mutants in I-2 were shown to have a reduced capacity to hydrolyze ATP (Tameling et al. 2006). These findings indicated that hydrolysis is not a requirement for $\mathrm{R}$ protein activation, and it was proposed, although not demonstrated, that the mutated and autoactive proteins were trapped in an ATP-bound state. Support for this also came from biochemical and structural studies of nonplant STAND proteins, including Apaf-1, MalT, and CED4, in which ATP-bound states are associated with the activated forms of these proteins (Bao et al. 2005; Kim et al. 2005; Marquenet and Richet 2007; Qi et al. 2010). There subsequently appears to be an overall acceptance within the R-protein literature, despite the absence of direct experimental validation, that an active $\mathrm{R}$ protein is bound to ATP. In this study, we found that, while wild-type $M$ copurifies with ADP, an autoactive MHD mutant copurifies with ATP and ADP. Our study provides direct evidence that, when bound with ATP, the M protein can activate the HR. It is, therefore, tempting to speculate that, as a consequence of $\mathrm{M} / \mathrm{AvrM}$ interaction, $\mathrm{M}$ progresses from an inactive to an active state that involves the exchange of ADP to ATP.

How this single mutation in the MHD motif can change the protein's preference or interaction with a bound nucleotide, or both, remains unclear. To provide some clues, we draw on functional studies of other $\mathrm{R}$ proteins and the structure and function information from nonplant STAND proteins. The ARC2 domain, in which the MHD motif resides, plays a crucial role in $\mathrm{R}$ protein function, as many gain-of-function mutations map to this region (Bendahmane et al. 2002; de la Fuente van Bentem et al. 2005; Howles et al. 2005; van Ooijen et al. 2008a). Independent studies of $\mathrm{R}$ proteins $\mathrm{Rx}$ and Mi-1.2 also suggest that the ARC2 domain is involved in maintaining both the autoinhibited state in the absence of the effector and the activated state when the effector is present (Rairdan and Moffett 2006; van Ooijen et al. 2008b). Currently, structural information of the ARC2 domain is unavailable for $\mathrm{R}$ proteins, however, the structure of this domain in Apaf-1 and CED4 shows a winged helix domain (Riedl et al. 2005; Yan et al. 2005). Riedl and associates (2005) solved the crystal structure of Apaf-1 in the ADP-bound inactive state and suggested that, for Apaf-1 to oligomerize into the active pro-caspase- 9 activating apoptosome, the ARC2 domain would require significant reorientation (Riedl et al. 2005). Modeling studies of STAND proteins (Danot et al. 2009) and the low-resolution structural studies of the Apaf-1 apoptosome (Yuan et al. 2010) have since provided further evidence to support such reorientation. In addition, the recent crystal structure of the CED4 apoptosome (active state) highlights the importance of the ARC2 domain in protein oligomerization. The authors speculate that this domain plays an important role in moderating ATP binding, hydrolysis in NB-ARC proteins, or both (Qi et al. 2010). These data provide compelling evidence that the ARC2 domain plays an essential role in the regulation and activation of STAND proteins; however, the role that individual motifs (such as MHD) play in this process is open for speculation. While a clearly distinguishable MHD motif is absent from CED-4, an equivalent motif is recognizable in Apaf-1. This LHD motif helps coordinate the binding of the $\beta$-phosphate of ADP and links the ARC2 domain of the protein to the nucleotide-binding pocket (Riedl et al. 2005). The same functional role has been predicted from an Apaf-1-derived model of the I2 NB-ARC region. From this model, it was suggested that disruption of the aspartate would abolish the interaction between the histidine and the ADP molecule and create a more open protein conformation (van Ooijen et al. 2008a). Similar structural modeling of $M$ revealed a structural conservation of the MHD motif consistent with that for I-2 (data not shown).

Taken together, it could be suggested that the reduced capacity to bind ADP resulting from a more open NB-ARC conformation would provide the characteristics conducive for the mutated protein to preferentially bind ATP and, thus, take on the form of an active protein. An alternative yet equally valid hypothesis is that, under normal conditions, the M protein first binds ATP and undergoes a round of hydrolysis to generate the resting state. This situation is consistent with a biochemical study of Apaf-1, whereby dATP binding and hydrolysis was shown to precede activation through nucleotide exchange (Kim et al. 2005). Mutation within the MHD motif of M may prevent ATP hydrolysis, effectively preventing the protein reaching a regulated off state. Unfortunately, in the absence of further biochemical and structural information, of both the inactive and active state of $\mathrm{M}$, the precise functional role of the MHD motif is unclear.

\section{A model of $\mathbf{R}$ protein activation.}

Collectively, the information obtained from this biochemical and in planta study of the flax $\mathrm{M}$ protein provides important insights into the protein's function. Our results indicate that flax $\mathrm{R}$ proteins in an inactive or off state are bound to ADP, and through the investigation of an autoactive mutant, we suggest that binding of ATP is a feature of protein activation. However, it is necessary to stress that an ADP-bound, autoinhibited $\mathrm{R}$ protein model may not hold true for all $\mathrm{R}$ proteins of the NB-ARC-LRR class. A revised model of NB-ARC protein activation has recently been proposed, in which $\mathrm{R}$ proteins such as RPS2 and RPM1 may always exist in an ATP-bound conformation (Qi et al. 2010). In such a model, R protein activation occurs when the effector molecule disrupts the influence of a negative regulator, in this case RIN4. This links the mode of function of RPS2/RPM1 to that of the Caenorhabditis elegans cell death protein CED4.

In terms of the flax $\mathrm{M}$ protein, the availability of more pure protein preparations will enable us to determine the nucleotide-binding and dissociation kinetics of the protein and deter- 
mine the role, if any, of nucleotide hydrolysis in protein function. In planning these experiments, we remain cognizant of the potential need for other, yet to be identified, factors that are required for this transition in nucleotide binding of $M$ to take place. Recently, structure and function studies of the TIR domain of L6 and the CC domain of the MLA protein both reported the requirement of protein self-association or dimerization in the signaling of pathogen-induced program cell death (Bernoux et al. 2011; Maekawa et al. 2011). In the future, it will be intriguing to assess these features in the context of an activated full-length protein and the involvement of ADP/ATP binding. We also intend to decipher the biochemical consequences to the $M$ protein following incubation with the purified effector protein AvrM. With the model of R-protein activation in mind, an ADP/ATP exchange event that occurs in M may be biased towards an ATP-bound state after effector interaction. However, any such hypotheses need to be tested experimentally.

\section{MATERIALS AND METHODS}

\section{Plasmid constructs for Pichia pastoris expression.}

Point mutations were introduced into the $M$ coding sequence in the pPICZ expression vector (Invitrogen, Carlsbad, CA, U.S.A.) using Phusion DNA polymerase site-directed mutagenesis (SDM) (Finnzymes, Keilaranta, Finland). The primers used to introduce the $\mathrm{M}^{\mathrm{K} 286 \mathrm{~L}}, \mathrm{M}^{\mathrm{D} 364 \mathrm{E}}$, and $\mathrm{M}^{\mathrm{D} 555 \mathrm{~V}}$ mutations are specified in Supplementary Table 1. PCR products were digested with DpnI and were electroporated into E. coli (strain DH10B), and clones were fully sequenced to confirm their integrity.

\section{Protein expression.}

Transformation of $P$. pastoris and test expression analysis was performed as previously described by Schmidt and associates (2007). A $P$. pastoris clone demonstrated to successfully express a desired $\mathrm{M}$ protein was used to inoculate $10 \mathrm{ml}$ of BMGY (buffered glycerol-complex medium) containing 100 $\mu \mathrm{g}$ of zeocin per milliliter (Zeocin was added for P. pastoris selection). This starter culture was grown overnight at $30^{\circ} \mathrm{C}$ with $200 \mathrm{rpm}$ shaking and was used to inoculate $100 \mathrm{ml}$ of BMGY containing $100 \mu \mathrm{g}$ of ampicillin per milliliter (ampicillin was added to suppress the growth of bacterial contaminants), which was incubated with shaking at $30^{\circ} \mathrm{C}$ for $72 \mathrm{~h}$. Cells were harvested by centrifugation at $3,000 \times g$ for $10 \mathrm{~min}$ in a Sorvall GSA rotor, the supernatant was discarded and the pellet was resuspended in BMMY (buffered methanol-complex medium) induction media containing $100 \mu \mathrm{g}$ of ampicillin per milliliter. After incubation with shaking at $15^{\circ} \mathrm{C}$ for $72 \mathrm{~h}$ (with the addition of $0.5 \%$ methanol every $24 \mathrm{~h}$ ), the cells were harvested as above. Cells were washed with $20 \mathrm{mM}$ Tris, $\mathrm{pH}$ $7.5,150 \mathrm{mM} \mathrm{NaCl}, 5 \mathrm{mM}$ EDTA, and were snap frozen in liquid nitrogen and were either stored at $-80^{\circ} \mathrm{C}$ or used immediately. Six grams of wet cell pellet was typically obtained from $100 \mathrm{ml}$ of culture and was split into 3-g pellets for storage and protein purification.

\section{Protein purification.}

P. pastoris cells expressing M, L6, mutants of the M protein, or the empty vector were resuspended in three volumes of cell lysis buffer (50 mM Tris $\left(\mathrm{Cl}^{-}\right), \mathrm{pH} 8.0,150 \mathrm{mM} \mathrm{NaCl}, 10 \%$ (wt/vol) glycerol, $0.25 \mathrm{mM}$ TritonX-100 (TX-100), $20 \mathrm{mM}$ $\beta$-mercaptoethanol (BME) and $1 \mathrm{mM}$ phenyl-methylsulfonyl fluoride, $1 \mathrm{mM}$ benzamidine, $1 \mathrm{mM}$ p-aminobenzamidine, 5 $\mathrm{mM} \varepsilon$-amino-n-caproic acid. Lysis was performed by three sequential passes through a precooled $\left(-20^{\circ} \mathrm{C}\right)$ French Press (Aminco, Urbana, IL, U.S.A.) at 5,000 to 8,000 psi. Unlysed cells and cell debris were removed by centrifugation at $10,000 \times$ $g$ for $15 \mathrm{~min}$ at $4^{\circ} \mathrm{C}$ in a Sorvall GSA. The supernatant was ultracentrifuged at $100,000 \times g$ for $45 \mathrm{~min}$ at $4^{\circ} \mathrm{C}$ in a Beckman Ti60 or Ti45 rotor. Cell lysates were titrated to $\mathrm{pH} 7.7$ to 8.0 and were loaded onto a 3-ml NiA column (Ni-Sepharose 6 Fast Flow, Amersham Biosciences, Piscataway, NJ, U.S.A.) that had been preequilibrated with $20 \mathrm{mM}$ Tris $\left(\mathrm{Cl}^{-}\right), \mathrm{pH} 8,130$ $\mathrm{mM} \mathrm{NaCl}, 0.25 \mathrm{mM}$ TX-100, $5 \mathrm{mM}$ BME, and $10 \mathrm{mM}$ imidazole. The column was washed with 10 column volumes $(\mathrm{c} / \mathrm{v})$ of NiA equilibration buffer containing $55 \mathrm{mM}$ imidazole. $\mathrm{R}$ proteins were eluted from the column with $5 \mathrm{c} / \mathrm{v}$ of the equilibration buffer containing $250 \mathrm{mM}$ imidazole. Prior to concentration using an ultracentrifugal device (30-kDa cut-off) (Amicon, Beverly, MA, U.S.A.), $35 \mathrm{ml}$ of equilibration buffer was added to the eluted protein sample to reduce the total imidazole concentration to $75 \mathrm{mM}$ to prevent formation of soluble protein aggregates. Protein samples were concentrated to $1 \mathrm{ml}$ in preparation for ATP/ADP quantification studies or further separation by GF. Immunoblot analysis of M and L6 proteins was performed with anti-M- and anti-His-specific antibodies, respectively.

\section{Gel filtration.}

A S200PG (HiLoad 16/60 Superdex 200 Prep Grade, Amersham Biosciences) GF column was equilibrated with $1.5 \mathrm{c} / \mathrm{v}$ of $20 \mathrm{mM}$ Tris $\left(\mathrm{Cl}^{-}\right), \mathrm{pH} 7.5,150 \mathrm{mM} \mathrm{NaCl}, 10 \%$ (wt/vol) glycerol, $10 \mathrm{mM}$ magnesium acetate, $1 \mathrm{mM}$ dithiothreitol. Protein samples were separated at $2 \mathrm{ml} / \mathrm{min}$, and 2-ml fractions were collected. The S200PG column was calibrated with proteins of known molecular weight (Sigma-Aldrich, St Louis).

\section{Nucleotide quantification assay.}

Nucleotide quantification was performed using the Adenosine 5'-triphosphate bioluminescent assay kit (Sigma-Aldrich). Purified triplicate $\mathrm{M}$ or L6 protein samples were heated to $98^{\circ} \mathrm{C}$ for $5 \mathrm{~min}$, followed by centrifugation at $14,000 \times g$ for $2 \mathrm{~min}$ at $4{ }^{\circ} \mathrm{C}$ to remove precipitated protein. To $100 \mu \mathrm{l}$ of each sample, $150 \mu$ of pyruvate kinase buffer $(125 \mathrm{mM}$ Tris-acetate, $\mathrm{pH}$ 7.4, $5 \mathrm{mM}$ phosphoenolpyruvate, $2.5 \mathrm{mM} \mathrm{MgSO}_{4}$ ) was added. For ADP measurements, 31 units of pyruvate kinase (PK) was added, and samples were incubated at room temperature for 30 min to convert the ADP into ATP, before samples were boiled for $5 \mathrm{~min}$ and centrifuged for $2 \mathrm{~min}$ at $14,000 \times g$ and $4^{\circ} \mathrm{C}$ to remove the PK. The luminescence assays performed involve the luciferase-catalyzed conversion of ATP, luciferin, and $\mathrm{O}_{2}$ to AMP, oxyluciferin, $\mathrm{CO}_{2}$, and light, in which, using saturating levels of luciferin, light output (luminescence) is linearly proportional to ATP concentration. A $10-\mu 1$ sample was added to $100 \mu \mathrm{l}$ of ATP assay mix, prepared at a dilution of 1:10 using the buffer supplied. Luminescence output was measured in millivolts, using a 1250 luminometer (BioOrbit, Turku, Finland). ATP $\left(2 \times 10^{-7}\right.$ or $\left.2 \times 10^{-8} \mathrm{M}\right)$ was added to each reaction as an internal standard. ADP concentration was measured as the difference between the ATP detected in samples with and without PK. Triplicate samples were averaged to give a single datapoint. For quantification experiments (Fig. 3), the percentage ADP/ATP occupancy values represent the mean, which was calculated from four independent purifications originating from two independently grown cell culture expressions.

\section{Protein quantification.}

Five microliters of proteins of interest were separated by SDS-PAGE. Gels were stained overnight in the dark with the fluorescent stain Sypro Ruby (Bio-Rad, Gladesville, Australia). After destaining in $10 \%$ ( $\mathrm{vol} / \mathrm{vol})$ methanol and $7 \%$ ( $\mathrm{vol} / \mathrm{vol})$ acetic acid for $1 \mathrm{~h}$, the gels were visualized and the image captured, using the VersaDoc imaging system (Bio-Rad), using the 
following Sypro Ruby settings: 520LP UV TRANS with $1 \times$ gain and $1 \times 1$ bin with an exposure time between 30 and $60 \mathrm{~s}$. Protein bands were quantified using the Quantity One software package (Bio-Rad). A BSA standard curve was run on each gel and was used to determine protein concentration of full-length $\mathrm{M}$ proteins run on the same gel and stained under the same conditions. Protein concentration estimates were performed in duplicate. $\mathrm{M}$ protein concentrations used in the quantification assays ranged from 50 to $150 \mu \mathrm{g} / \mathrm{ml}$.

\section{Agrobacterium-mediated transient expression.}

A pENTR-1A (Invitrogen) vector containing a genomic version of the $M$ gene, fused in frame with a sequence encoding a single HA epitope tag at the C-terminus, was provided by A. M. Catanzariti. Mutations analogous to those tested in vitro were engineered by SDM and were verified by sequencing of the complete $M$ gene. $M$ genes were then transferred to the pEarleygate 100 binary vector (Earley et al. 2006) by an LR clonase reaction (Invitrogen) and were sequenced across the recombination junction points. Binary vectors were then transferred to the Agrobacterium sp. strain GV3101 by electroporation, and transformants were selected by plating on gentamycin $(50 \mu \mathrm{g} / \mathrm{ml})$, rifampicin $(25 \mu \mathrm{g} / \mathrm{ml})$, and kanamycin 50 $(\mu \mathrm{g} / \mathrm{ml})$. Agrobacterium transformants with the binary vector pTNSpec (Catanzariti et al. 2006) containing the AvrM and avrM genes were cultured in gentamycin $(50 \mu \mathrm{g} / \mathrm{ml})$, rifampicin $(25 \mu \mathrm{g} / \mathrm{ml})$, and tetracycline $(5 \mu \mathrm{g} / \mathrm{ml})$. All Agrobacterium strains used in this study were cultured, harvested, and resuspended to an optical density at $600 \mathrm{~nm}$ of 1.0 according to the methods of Catanzariti and associates (2010). In coinfiltration experiments, equal volumes of resuspended Agrobacterium cultures were mixed and infiltrated. Infiltrations were performed on flax cotyledons (Hoshangabad cultivar) grown and infiltrated according to Howles and associates (2005), with the exception that the cotyledons were infiltrated 9 days after germination.

\section{Transient protein detection from flax cotyledons.}

Total protein was extracted from two infiltrated flax cotyledons according to the methods for infiltrated tobacco leaf tissue described by Catanzariti and associates (2010). HA-tagged $\mathrm{M}$ proteins were separated by $10 \%$ SDS-PAGE and were transferred onto nitrocellulose membrane before analysis by immunoblot, using mouse anti-HA (clone 16B12; Covance, Emeryville, CA, U.S.A.) and horseradish peroxidase-conjugated goat anti-mouse (Rockland, Gilbertsville, PA, U.S.A.). Signals were visualized using SuperSignal West Pico chemiluminescence substrate (Pierce, Rockford, IL, U.S.A.) and a KODAK X-omat-100 developer.

\section{Multiple-sequence alignment of the NB-ARC region of M, other R proteins, Apaf-1, and CED-4.}

The multiple sequence alignment was performed with the alignment program ClustalW (Thompson et al. 1994). The protein sequences in the alignment have the UniProtKB accession numbers provided:

NB: human Apaf-1, residues 108 to 405, O14727; nematode CED-4, residues 113 to 496, P30429;

R proteins: flax M, residues 236 to 566, P93244: flax L6, residues 221 to 552, Q40253; tobacco $\mathrm{N}$, residues 171 to 500, Q40392; RPS4, residues 191 to 520, Q9XGM3; RPS2, residues 139 to 484, Q42484; RPM1, residues 154 to 516, Q39214; potato Rx, residues 124 to 471, Q9XGF5; and tomato I-2, residues 153 to 506, Q9XET3; Mi-1, residues 505 to 852, O81137.

The alignment was annotated further using the GeneDoc program (GeneDoc software website).

\section{ACKNOWLEDGMENTS}

We thank A.-M. Catanzariti for kindly supplying the M genomic clone in the Gateway cloning system and T. Ashton for critical reading of this manuscript and helpful discussions. This research was supported by the Australian Research Council and the Grains Research and Development Corporation. B. Kobe is an Australian Resource Council Federation Fellow and a National Health and Medical Research Council (NHMRC) Honorary Research Fellow.

\section{LITERATURE CITED}

Ade, J., Deyoung, B. J., Golstein, C., and Innes, R. W. 2007. Indirect activation of a plant nucleotide binding site-leucine-rich repeat protein by a bacterial protease. Proc. Natl. Acad. Sci. U.S.A. 104:2531-2536.

Albrecht, M., and Takken, F. L. W. 2006. Update on the domain architectures of NLRs and R proteins. Biochem. Biophys. Res. Commun. 339:459-462.

Anderson, P. A., Lawrence, G. J., Morrish, B. C., Ayliffe, M. A., Finnegan, E. J., and Ellis, J. G. 1997. Inactivation of the flax rust resistance gene $\mathrm{M}$ associated with loss of a repeated unit within the leucine-rich repeat coding region. Plant Cell 9:641-651.

Bao, Q., Lu, W., Rabinowitz, J. D., and Shi, Y. 2007. Calcium blocks formation of apoptosome by preventing nucleotide exchange in Apaf-1. Mol. Cell 25:181-192.

Bao, Q., Riedl, S. J., and Shi, Y. 2005. Structure of Apaf-1 in the autoinhibited form: A critical role for ADP. Cell Cycle 4:1001-1003.

Bendahmane, A., Farnham, G., Moffett, P., and Baulcombe, D. C. 2002 Constitutive gain-of-function mutants in a nucleotide binding site-leucine rich repeat protein encoded at the Rx locus of potato. Plant $\mathrm{J}$. 32:195-204.

Bent, A. F., and Mackey, D. 2007. Elicitors, effectors, and R genes: The new paradigm and a lifetime supply of questions. Annu. Rev. Phytopathol. 45:399-436.

Bernoux, M., Ve, T., Williams, S., Warren, C., Hatters, D., Valkov, E., Zhang, X., Ellis, J. G., Kobe, B., and Dodds, P. N. 2011. Structural and functional analysis of a plant resistance protein TIR domain reveals interfaces for self-association, signaling, and autoregulation. Cell Host Microbe 9:200-211.

Boyes, D. C., Nam, J., and Dangl, J. L. 1998. The Arabidopsis thaliana RPM1 disease resistance gene product is a peripheral plasma membrane protein that is degraded coincident with the hypersensitive response. Proc. Natl. Acad. Sci. U.S.A. 95:15849-15854.

Catanzariti, A.-M., Dodds, P. N., Lawrence, G. J., Ayliffe, M. A., and Ellis, J. G. 2006. Haustorially expressed secreted proteins from flax rust are highly enriched for avirulence elicitors. Plant Cell 18:243-256.

Catanzariti, A.-M., Dodds, P. N., Ve, T., Kobe, B., Ellis, J. G., and Staskawicz, B. J. 2010. The AvrM effector from flax rust has a structured C-terminal domain and interacts directly with the $\mathrm{M}$ resistance protein. Mol. Plant-Microbe Interact. 23:49-57.

Chisholm, S. T., Coaker, G., Day, B., and Staskawicz, B. J. 2006. Host-microbe interactions: Shaping the evolution of the plant immune response. Cell 124:803-814.

Danot, O., Marquenet, E., Vidal-Ingigliardi, D., and Richet, E. 2009. Wheel of life, wheel of death: A mechanistic insight into signaling by STAND Prot. Struct. 17:172-182.

De La Fuente Van Bentem, S., Vossen, J. H., De Vries, K. J., Van Wees, S. Tameling, W. I. L., Dekker, H. L., De Koster, C. G., Haring, M. A., Takken, F. L. W., and Cornelissen, B. J. C. 2005. Heat shock protein 90 and its co-chaperone protein phosphatase 5 interact with distinct regions of the tomato I-2 disease resistance protein. Plant J. 43:284-98.

Dinesh-Kumar, S. P., Tham, W. H., and Baker, B. J. 2000. Structure-function analysis of the tobacco mosaic virus resistance gene N. Proc. Natl. Acad. Sci. U.S.A. 97:14789-14794.

Dodds, P. N., and Rathjen, J. P. 2010. Plant immunity: Towards an integrated view of plant-pathogen interactions. Nat. Rev. Genet. 11:539548.

Dodds, P. N., Lawrence, G. J., Catanzariti, A.-M., Teh, T., Wang, C.-I. A., Ayliffe, M. A., Kobe, B., and Ellis, J. G. 2006. Direct protein interaction underlies gene-for-gene specificity and coevolution of the flax resistance genes and flax rust avirulence genes. Proc. Natl. Acad. Sci. U.S.A. 103:8888-8893.

Earley, K. W., Haag, J. R., Pontes, O., Opper, K., Juehne, T., Song, K., and Pikaard, C. S. 2006. Gateway-compatible vectors for plant functional genomics and proteomics. Plant J. 45:616-629.

Faustin, B., Lartigue, L., Bruey, J.-M., Luciano, F., Sergienko, E., BaillyMaitre, B., Volkmann, N., Hanein, D., Rouiller, I., and Reed, J. C. 2007. Reconstituted NALP1 inflammasome reveals two-step mechanism of caspase-1 activation. Mol. Cell 25:713-724. 
Greenberg, J. T. 1997. Programmed cell death in plant-pathogen interactions. Annu. Rev. Plant Physiol. Plant Mol. Biol. 48:525-545.

Hanson, P. I., and Whiteheart, S. W. 2005. AAA+ proteins: Have engine, will work. Nat. Rev. Mol. Cell Biol. 6:519-529.

Howles, P., Lawrence, G., Finnegan, J., Mcfadden, H., Ayliffe, M., Dodds, P., and Ellis, J. 2005. Autoactive alleles of the flax L6 rust resistance gene induce non-race-specific rust resistance associated with the hypersensitive response. Mol. Plant-Microbe Interact. 18:570-582.

Jones, J. D. G., and Dangl, J. L. 2006. The plant immune system. Nature, 444:323-329.

Kim, H.-E., Du, F., Fang, M., and Wang, X. 2005. Formation of apoptosome is initiated by cytochrome c-induced dATP hydrolysis and subsequent nucleotide exchange on Apaf-1. Proc. Natl. Acad. Sci. U.S.A. 102:17545-17550.

Krasileva, K. V., Dahlbeck, D., and Staskawicz, B. J. 2010. Activation of an Arabidopsis resistance protein is specified by the in planta association of Its leucine-rich repeat domain with the cognate oomycete effector. Plant Cell 22:1-15.

Lawrence, G. J., Finnegan, E. J., Ayliffe, M. A., and Ellis, J. G. 1995. The L6 gene for flax rust resistance is related to the Arabidopsis bacterial resistance gene RPS2 and the tobacco viral resistance gene N. Plant Cell 7:1195-1206.

Leipe, D. D., Koonin, E. V., and Aravind, L. 2004. STAND, a class of P-loop NTPases including animal and plant regulators of programmed cell death: Multiple, complex domain architectures, unusual phyletic patterns, and evolution by horizontal gene transfer. J. Mol. Biol. 343:1-28.

Maekawa, T., Cheng, W., Spiridon, L. N., Toller, A., Lukasik, E., Saijo, Y., Liu, P., Shen, Q. H., Micluta, M. A., Somssich, I. E., Takken, F. L., Petrescu, A. J., Chai, J., and Schulze-Lefert, P. 2011. Coiled-coil domain-dependent homodimerization of intracellular barley immune receptors defines a minimal functional module for triggering cell death. Cell Host Microbe 9:187-199.

Marquenet, E., and Richet, E. 2007. How integration of positive and negative regulatory signals by a STAND signaling protein depends on ATP hydrolysis. Mol. Cell 28:187-199.

Meyers, B. C., Dickerman, A. W., Michelmore, R. W., Sivaramakrishnan, S., Sobral, B. W., and Young, N. D. 1999. Plant disease resistance genes encode members of an ancient and diverse protein family within the nucleotide-binding superfamily. Plant J. 20:317-332.

Moffett, P., Farnham, G., Peart, J., and Baulcombe, D. C. 2002. Interaction between domains of a plant NBS-LRR protein in disease resistancerelated cell death. EMBO (Eur. Mol. Biol. Organ.) J. 21:4511-4519.

Panstruga, R., and Dodds, P. N. 2009. Terrific protein traffic: The mystery of effector protein delivery by filamentous plant pathogens. Science 324:748-750.

Qi, S., Pang, Y., Hu, Q., Liu, Q., Li, H., Zhou, Y., He, T., Liang, Q., Liu, Y., Yuan, X., Luo, G., Li, H., Wang, J., Yan, N., and Shi, Y. 2010. Crystal structure of the Caenorhabditis elegans apoptosome reveals an octameric assembly of CED-4. Cell 141:446-457.

Rairdan, G. J., and Moffett, P. 2006. Distinct domains in the ARC region of the potato resistance protein Rx mediate LRR binding and inhibition of activation. Plant Cell 18:2082-2093.

Riedl, S. J., Li, W., Chao, Y., Schwarzenbacher, R., and Shi, Y. 2005. Structure of the apoptotic protease-activating factor 1 bound to ADP Nature 434:926-933.

Schmidt, S. A., Williams, S. J., Wang, C.-I. A., Sornaraj, P., James, B.,
Kobe, B., Dodds, P. N., Ellis, J. G., and Anderson, P. A. 2007. Purification of the $M$ flax-rust resistance protein expressed in Pichia pastoris. Plant J. 50:1107-1117.

Takken, F. L., Albrecht, M., and Tameling, W. I. 2006. Resistance proteins: Molecular switches of plant defence. Curr. Opin. Plant Biol. 9:383-390.

Tameling, W. I. L., Elzinga, S. D. J., Darmin, P. S., Vossen, J. H., Takken, F. L. W., Haring, M. A., and Cornelissen, B. J. C. 2002. The tomato R gene products I-2 and MI-1 are functional ATP binding proteins with ATPase activity. Plant Cell 14:2929-2939.

Tameling, W. I. L., Vossen, J. H., Albrecht, M., Lengauer, T., Berden, J. A., Haring, M. A., Cornelissen, B. J. C., and Takken, F. L. W. 2006. Mutations in the NB-ARC domain of I-2 that impair ATP hydrolysis cause autoactivation. Plant Physiol. 140:1233-1245.

Tao, Y., Yuan, F., Leister, R. T., Ausubel, F. M., and Katagiri, F. 2000. Mutational analysis of the Arabidopsis nucleotide binding site-leucinerich repeat resistance gene RPS2. Plant Cell 12:2541-2554.

Thompson, J. D., Higgins, D. G., and Gibson, T. J. 1994. Clustal-W-Improving the sensitivity of progressive multiple sequence alignment through sequence weighting, position-specific gap penalties and weight matrix choice. Nucleic Acids Res. 22:4673-4680.

Traut, T. W. 1994. The functions and consensus motifs of nine types of peptide segments that form different types of nucleotide-binding sites Eur. J. Biochem. 222:9-19.

Ueda, H., Yamaguchi, Y., and Sano, H. 2006. Direct interaction between the tobacco mosaic virus helicase domain and the ATP-bound resistance protein, $\mathrm{N}$ factor during the hypersensitive response in tobacco plants. Plant Mol. Biol. 61:31-45.

Van Der Biezen, E. A., and Jones, J. D. 1998. The NB-ARC domain: A novel signalling motif shared by plant resistance gene products and regulators of cell death in animals. Curr. Biol. 8:R226-227.

Van Ooijen, G., Mayr, G., Kasiem, M. M. A., Albrecht, M., Cornelissen, B. J. C., and Takken, F. L. W. 2008a. Structure-function analysis of the NB-ARC domain of plant disease resistance proteins. J. Exp. Bot. 59:1383-1397.

Van Ooijen, G., Mayr, G., Albrecht, M., Cornelissen, B. J. C., and Takken, F. L. W. 2008b. Transcomplementation, but not physical association of the CC-NB-ARC and LRR domains of tomato R protein Mi-1.2 is altered by mutations in the ARC2 subdomain. Mol. Plant 1:401-10.

Weaver, M. L., Swiderski, M. R., Li, Y., and Jones, J. D. G. 2006. The Arabidopsis thaliana TIR-NB-LRR R-protein, RPP1A: Protein localization and constitutive activation of defence by truncated alleles in tobacco and Arabidopsis. Plant J. 47:829-40.

Yan, N., Chai, J., Lee, E. S., Gu, L., Liu, Q., He, J., Wu, J.-W., Kokel, D., Li, H., Hao, Q., Xue, D., and Shi, Y. 2005. Structure of the CED-4CED-9 complex provides insights into programmed cell death in Caenorhabditis elegans. Nature 437:831-7.

Yuan, S., Yu, X., Topf, M., Ludtke, S. J., Wang, X., and Akey, C. W. 2010. Structure of an apoptosome-procaspase-9 CARD complex. Structure 18:571-83.

\section{AUTHOR-RECOMMENDED INTERNET RESOURCE}

National Resource for Biomedical Supercomputing website: www.psc.edu/biomed/genedoc

GeneDoc software website: www.nrbsc.org/gfx/genedoc 